Asian Journal of Engineering and Applied Technology

ISSN 2249-068X Vol. 7 No. S2, 2018, pp. 26-29

(C) The Research Publication, www.trp.org.in

\title{
Fabrication and Analysis of Thermal Insulation Boards from Rice Husk
}

\author{
Deepak Dhand \\ Assistant Professor, Department of Mechanical Engineering, GNDEC, Ludhiana, Punjab, India \\ E-mail: dmechd@gmail.com
}

\begin{abstract}
There is an increased awareness to preserve the environment in the present day society. Rice Husk (RH),is the widely available agricultural wastes and is a serious concern for the environment. It is a potential material for use as alternative material in the construction and insulation industry. The particle board made from rice husk (RH) or rice husk ash (RHA), bonded by resin under the application of pressure and temperature. Urea formaldehyde is the organic resin used in general for interior use whereas phenol formaldehyde for external disclosure. The said resins are preferred for their water-resistant properties and better binding strength. The present study investigates the potential of rice husk reinforced boards by experimenting the different compositions and thicknesses. The objective is to perform a thermal analysis of the processed Rice husk boards. Boards made from rice husk are biodegradable unlike glass wool \& other synthetic insulations. After experimenting on different fabrication conditions, six samples were finalized and were tested for physical and thermal viability in their applications. This study found that by adding ash of rice husk, the density of board decreases with respect to the board of same weight and consisting of rice husk only. Moisture Content is higher in case of boards with RHA but is within permissible limits. RHA reinforced boards have improved thermal properties, which is desirable in case of insulation boards.

Keywords: Rice husk, Rice husk ash, Active silica, Preparation, Characterization, Thermal analysis
\end{abstract}

\section{INTRODUCTION}

In rice-producing countries, Rice husk (RH) is an abundantly available agricultural waste material. It is a natural occurrence as heath on rice grains during their growth period. In the end, during refining process, they are separated from the rice grains. These husks are of no mercantile interest [1]. As per the data available, the rice production amounts to approx. 400 million metric tons per annum, where more than $10 \%$ is husk [2].

Rice husk is a fibrous material with high silica content and exists as waste in rice mills. RH major constituents are cellulose, lignin, and ash, and vary with the diversity, climate and geographic site of growth. Pure silica can be obtained from the ash by acid-leaching procedure [3].The awareness to preserve the environment in the present day world has improved. The high content of silica in RH poses hindrance in the use as cattle fodder.

The recycling or reuse of the waste materials is a key step to protect the environment, with the sole aim to produce recycled materials competing with low-cost products and high value-added applications. Agriculture is a major business sector in India, where organic sources such as rice straw, oil palm, empty fruit bunch, sugar cane bagasse, coconut shell, and others are major agricultural remains. Improper management of these potential wastes may create an environmental issue.Out of all paddy, 78\% is received as a rice, broken rice and bran. So remaining $22 \%$ is a husk. Further, this husk is usually used as fuel in the rice mills to generate steam for the parboiling process.

This husk contains about $75 \%$ organic volatile matter and the balance $25 \%$ of the weight of this husk is converted into ash during the firing process, is known as rice husk ash (RHA). Many authors have concluded that RHA contains around having 87-97\% silica in a shapeless form and some amount of metallic impurity [1-6]. This silica has been shown to be a good material for the synthesis of very pure silicon, silicon nitride, silicon carbide and magnesium silicide $[1,7,8]$. The moisture content ranges from 8.68 to $10 \cdot 44 \%$ and the bulk density from 86 to $114 \mathrm{~kg} / \mathrm{m}^{3}$. This RHA is a great environment threat causing harm to the land and the surrounding area in which it is discarded.

\section{A. Husk Particle Boards}

Rice husks can be put to use as building material, fertilizer, insulation material or fuel. RH particle boards are one such material which is being considered as a possible substitute for wood \& wood-based boards. The particle board was first commercially built in West Germany in 1941, and the layered particle board was marketed in Switzerland in 1945. $\mathrm{RH}$ particle boards have widespread use in the building industry, furniture industry cabinets and automobile construction.

The production processes involve the introduction of synthetic resin between two heated plates in the hot press, and are subjected to a high pressure and temperature, to form a board which exits from the other end continuously.Fig. 1 shows the process of processing rice husk particle boards. 


\section{B. Potential Agro Materials for Thermal Insulation}

Thermal insulating materials are high energy consumers, from an environmental point of view. Thermal insulating materials based on agricultural products and waste have a clear advantage over conventional thermal insulating materials due to the low embodied energy. Some of the potential materials for insulation are Rice hulls (husk), corn stalks, bagasse, rice husk ash, coconut fibers, and wheat husk. Rice husks use also includes aggregate and fillers for concrete and board production, economical substitute for microsilica, absorbents for oils and chemicals and as a source of silicon, as insulation powder in steel mills. The table I shows the composition by weigth \% of rice husk.

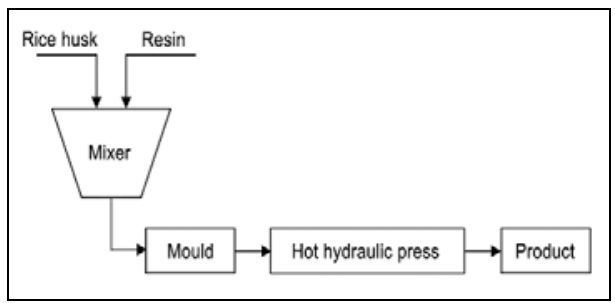

Fig. 1 Production of rice husk particle boards

TABLE I COMPOSITION OF RICE HUSK

\begin{tabular}{|l|l|}
\hline Composition weight & \% RH (by wt. \%) \\
\hline $\mathrm{SiO}_{2}$ & $18.80-22.30$ \\
\hline Lignin & $9-20$ \\
\hline Cellulose & $28-38$ \\
\hline Protein & $1.90-3.0$ \\
\hline Fat & $0.30-0.80$ \\
\hline Other nutrients & $9.30-9.50$ \\
\hline
\end{tabular}

\section{EXPERIMENTAL SETUP}

The literature identifies that insulating materials are generally made from petroleum-based products and plastics which are serious threats to the environment. Further, the costs of raw materials are very high which makes the whole system expensive. Thus, there arises a need for alternative materials to be used for insulation. The material with better thermal resistance should be bio-degradable, besides being inexpensive.

\section{A. Pre-treatment}

The pre-treatment of rice husk includes washing with water so as to remove dirt and other contaminants present in them and later dried in an oven at about $100^{\circ} \mathrm{C}$ for nearly $24 \mathrm{~h}$.

\section{B. Rice Husk and Binders}

The reasons behind the use of $\mathrm{RH}$ in the construction industry are its high availability, low bulk density, toughness, abrasiveness, resistance to weathering and unique composition. As per the referred literature, the rice husk is also used for power generation and processing of paddy, which is done in boilers. On burning, residue is Rice Husk Ash, which is about 25\% of rice husk. Table 3 and Table 4 shows the properties, and the percentage weight of the constituents of RHA ((Source: http//Building Materials and technology promotion council (BMTPC)).

TABLE II TYPICAL ANALYSIS OF RICE HUSK [9]
\begin{tabular}{|l|l|}
\hline Property & Range \\
\hline Bulk density $\left(\mathrm{Kg} / \mathrm{m}^{3)}\right.$ & $96-160$ \\
\hline Hardness (Mohr scale ) & $5-6$ \\
\hline Ash content \% & $22-29$ \\
\hline Carbon \% & 35 \\
\hline Hydrogen\% & $4-5$ \\
\hline Oxygen \% & $31-37$ \\
\hline Nitrogen \% & $0.23-0.32$ \\
\hline Sulphur \% & $0.04-0.08$ \\
\hline Moisture \% & $8-9$ \\
\hline
\end{tabular}

The work samples were prepared by using the following base materials namely rice husk, rice husk ash, wheat husk, and the binders namely urea formaldehyde resin fortified with melamine, phenol-formaldehyde. The melamine, which comprise a polyvinyl acetate emulsion together with a metal chloride and an ammonium salts used as hardener for use in urea-formaldehyde and urea-melamineformaldehyde based adhesives.The adhesive composition comprising the above hardener, and urea-melamineformaldehyde or a urea-formaldehyde resin provides an increased curing rate, an acceptable viscosity, better adhesion and greater tolerance towards substrate type.Properties of rice husk and the composition of rice husk has been shown in Table I and Table II, respectively.

\begin{tabular}{|l|l|}
\multicolumn{2}{c}{ TABLe III Properties OF RHA } \\
\hline Name & Physical Properties \\
\hline Density & 2.06 \\
\hline Average particle size (microns) & $5.85-6.86$ \\
\hline Specific surface area $\left(\mathrm{m}^{2} / \mathrm{kg}\right)$ & $32.4-112.1$ \\
\hline Mineralogy & Non crystalline \\
\hline Shape and texture & Irregular, cellular \\
\hline Thermal Conductivity $(\mathrm{W} / \mathrm{mK})$ & 0.018 \\
\hline
\end{tabular}

TABLE IV CONSTITUENTS OF RHA

\begin{tabular}{|l|l|}
\hline Constituents & \% by Wt. \\
\hline Silicon dioxide & 87.2 \\
\hline Aluminium oxide & 0.15 \\
\hline Ferric oxide & 0.16 \\
\hline Calcium oxide & 0.55 \\
\hline Magnesium Oxide & 0.35 \\
\hline Sodium Oxide & 1.12 \\
\hline Potassium Oxide & 3.68 \\
\hline Phosphorous Oxide & 0.50 \\
\hline Titanium Oxide & 0.01 \\
\hline Sulphur Oxide & 0.24 \\
\hline Carbon & 5.91 \\
\hline Loss on ignition & 8.55 \\
\hline
\end{tabular}




\section{MANUFACTURING RICE HUSKINSULATION BOARDS}

RH since being quite fibrous by nature requires slight energy input to prepare the husk for board manufacture. Its density is $<500 \mathrm{~kg} / \mathrm{m}^{3}$. The thermal and acoustic insulation properties in low density boards are better as compared to medium-density boards. Termites, wood-boring insects and wood decaying organisms are also not able to harm these boards.

\section{A. Fabrication using Hot Press}

Hot press was used for fabricating the boards. Boards were applied with a pressure up to $50 \mathrm{~kg} / \mathrm{cm}^{2}$ and temperature up to 135 deg. Celsius. The binder used was urea formaldehyde/Phenol formaldehyde. Melanin/ lignin were used as additives to extend the hardness with UF (only). Urea Formaldehyde is a synthetic resin which can be prepared in laboratory. UF resin provides a good strength to the particle boards and is extensively used in the industry. It also prevents the attack of pests on wood and particle boards. Melanin is a chemical compound and lignin is a biobased material which can eliminate the use of melanin chemical and other chemical protein. Although there was no significant difference in the physical properties of board produced.

Phenol formaldehyde resins are synthetic polymers obtained by the reaction of phenol or substituted phenol with formaldehyde, and find usage on the basis for Bakelite. It is widely used for the production of billiard balls, laboratory countertops, and as coatings and adhesives, which are produced by molding. Fig. 2 and Fig. 3 shows the pictures of processing of work specimens.

1. Samples of $8 \mathrm{~mm}, 9 \mathrm{~mm}, 7 \mathrm{~mm}, 4.5 \mathrm{~mm}, 5 \mathrm{~mm}$ thickness using rice husk as base material and urea formaldehyde (binder), melanin or lignin (extender) were made and tested.

2. Samples of same weight and dimensions were prepared by using Rice Husk ash as $10 \%$ of the rice husk by weight.

The RH specimen consisted of Rice Husk - $800-1000$ grams; Urea Formaldehyde/Phenol Formaldehyde: $20 \%$ of $\mathrm{RH}$; Melamine: $1 \%$ of RH, Protein hardener: $1 \%$ of RH and Rice Husk ash: $10 \%$ of RH. The operating Conditions at which the mixture was processed were pressure - 100-120 $\mathrm{kg} / \mathrm{cm}^{2}$ and Temperature: $135-145$ deg. Celsius. The details of the sample prepare is shown in Table V.

\section{B. Testing of Work Specimens}

The tests that were conducted as per IS 3129 and IS 2380 on the work specimen's samples for thermal conductivity. The thermal conductivity was determined by means of the guarded hot plate, as per ASTM test specification C177, "Standard Test Method for Steady-State Thermal Transmission Properties by means of the Guarded Hot Plate", as shown in Fig.4.
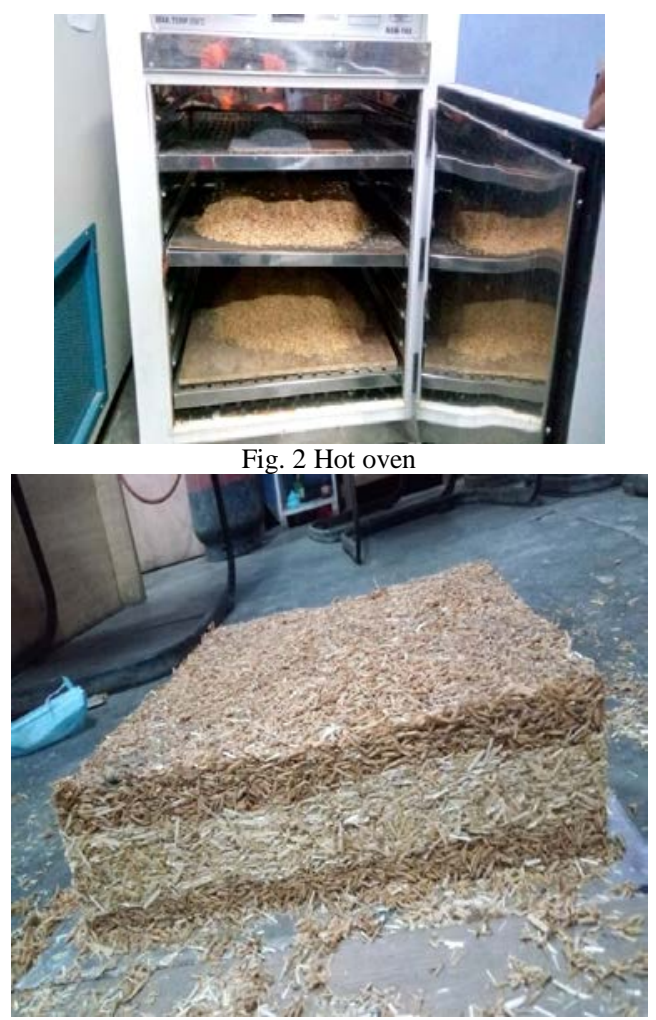

Fig. 3 Mixture before pressing in hot press

TABLE V DETAILS OF WORK SPECIMENS PROCESSED

\begin{tabular}{|l|l|l|l|}
\hline Specification & Thickness & $\begin{array}{l}\text { Base } \\
\text { Material }\end{array}$ & $\begin{array}{l}\text { Adhesive used } \\
\text { (Type/ weight) }\end{array}$ \\
\hline Sample 1 & $0.7 \mathrm{~cm}$ & $\begin{array}{l}\text { UF-160g; } \\
\text { Sodium } \\
\text { pentachlorephenate- } \\
8 \mathrm{~g} ; \\
\text { Melamine- 8 g }\end{array}$ \\
\hline Sample 2 & $1 \mathrm{~cm}$ & RH, 1000 g & $\begin{array}{l}\text { Sodium } \\
\text { pentachlorephenate- } \\
10 g ; \\
\text { Melamine- 10 g }\end{array}$ \\
\hline Sample 3 & $0.8 \mathrm{~cm}$ & $\begin{array}{l}\text { RH - 720 g } \\
\text { RHA - 80 }\end{array}$ & PF, 160 g \\
\hline $\begin{array}{l}\text { Sample 4 } \\
\text { (composite) }\end{array}$ & $1.1 \mathrm{~cm}$ & $\begin{array}{l}\text { RH- 900 g } \\
\text { RHA -100g }\end{array}$ & PF, 200 g \\
\hline $\begin{array}{l}\text { Sample 6 } \\
\text { (composite) }\end{array}$ & $1.1 \mathrm{~cm}$ & $\begin{array}{l}\text { RH- 600 g } \\
\text { WH- 200 g }\end{array}$ & PF, 160 g \\
\hline
\end{tabular}

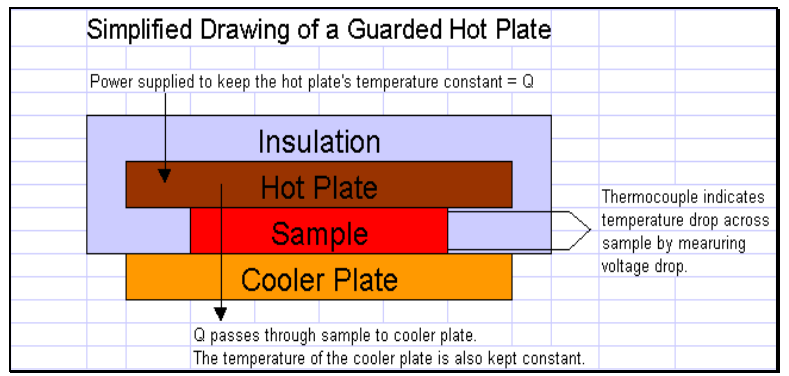

Fig. 4 General features of the guarded hot plate apparatus

\section{DISCUSSION}

The analysis of the results of the tests has been shown in Table 6 . The boards formed are medium density boards. The 
density varies from $0.73-0.90 \mathrm{~g} / \mathrm{cm}^{3}$. The density can be reduced by reducing the pressure while pressing the boards on a hot press, making a compromise on the strength of boards and the moisture content retained by boards during regular use.It has been found from the results obtained that by adding rice husk ash, the density of board decreases with respect to board of same weight and consisting of RH only.

\begin{tabular}{|c|c|c|c|c|c|c|}
\hline $\begin{array}{c}\text { Specifica } \\
\text { tion }\end{array}$ & $\begin{array}{c}\text { Thickn } \\
\text { ess } \\
(\mathrm{cm})\end{array}$ & $\begin{array}{c}\text { Dens } \\
\text { ity } \\
(\mathrm{g} / \mathrm{c} \\
\left.\mathrm{m}^{3}\right)\end{array}$ & $\begin{array}{c}\text { Ash } \\
\text { conte } \\
\text { nt } \\
(\% \text { of } \\
\mathrm{RH})\end{array}$ & $\begin{array}{c}\text { Moist } \\
\text { ure } \\
\text { conte } \\
\text { nt }\end{array}$ & $\begin{array}{c}\text { Thermal } \\
\text { Conducti } \\
\text { vity } \\
(\mathrm{W} / \mathrm{mK})\end{array}$ & $\begin{array}{c}\text { Resista } \\
\text { nce } \\
(\mathrm{K} / \\
\mathrm{W})\end{array}$ \\
\hline Sample 1 & 0.7 & 0.90 & $\mathrm{Nil}$ & $9.57 \%$ & 0.358 & 0.116 \\
\hline Sample 2 & 1 & 0.80 & $\mathrm{Nil}$ & $9.78 \%$ & 0.248 & 1.66 \\
\hline Sample 3 & 0.8 & 0.81 & $10 \%$ & $\begin{array}{c}10.34 \\
\%\end{array}$ & 0.231 & 1.144 \\
\hline Sample 4 & 1.1 & 0.73 & $10 \%$ & $\begin{array}{c}10.25 \\
\%\end{array}$ & 0.1925 & 2.380 \\
\hline $\begin{array}{c}\text { Sample } \\
\text { 5(compo } \\
\text { site) }\end{array}$ & 0.8 & 0.84 & $\mathrm{Nil}$ & $9.08 \%$ & 0.240 & 1.387 \\
\hline $\begin{array}{c}\text { Sample 6 } \\
\text { (composi } \\
\text { te) }\end{array}$ & 1.1 & 0.73 & $\mathrm{Nil}$ & $\begin{array}{c}10.26 \\
\%\end{array}$ & 0.18 & 2.548 \\
\hline
\end{tabular}

Moisture Content is higher in case of boards with RHA, but is within permissible limits. Thermal Properties are also improved with addition of rice husk ash. Thermal Conductivity reduces which is desirable in case of insulation boards.Thermal Conductivity of boards is found to be decreased with increase in thickness. Also the Conductivity is lesser in boards containing RHA. Composite boards (Sample 5 \& Sample 6) made with alternate layers of Wheat husk and Rice Husk are having the least thermal conductivity. Thermal Resistance of composite boards is least as compared to other boards. Hence, we can conclude that Thermal Resistance of boards can be further decreased by lowering the density of boards and by increasing the thickness as suitable acc. to space available. More Combinations of materials can be tried to improve the thermal resistance of boards.

\section{CONCLUSION}

The summary of the results which has been concluded on the basis of the analysis are as follows:

1. Thermal Conductivity of boards lies within the specified limit (i.e- $0.65 \mathrm{~W} / \mathrm{mK}$ ) in standard.
2. Thermal Conductivity of boards is found to be increased with increase in temperature of heater or amount of heat supplied.

3. Addition of Rice husk ash decreases the thermal conductivity of board.

4. Composite boards with layers of rice husk and wheat husk are having lower thermal conductivity than the boards composed of rice husk only and of same thickness.

Thermal insulation properties of board can be further improved with decrease in density and by making multiple alternate layers of rice husk and wheat husk particles.

\section{REFERENCES}

[1] C. Real, M.D. Alcala and J.M. Criado, "Preparation of silica fromrice husks,”Journal of the American Ceramic Society, Vol. 79, pp. 20122016, 1996.

[2] R. Conradt, P. Pimkhaokham and U. Leela-Adisorn, "Nano structured silica from rice husk,"Journal of Non-Crystalline Solids, Vol. 145, pp. 75-79,1992.

[3] J.M. Chenand F.W. Chang, "The chlorination kinetics of rice husk,"Indian Engineering Chemical Research ,Vol. 30, pp. 22412247, 1991.

[4] T.B. Ghosh, K.C. Nandi, H.N. Acharyaand D. Mukherjee, "Xrayphotoelectron spectroscopic analysis of amorphous silica Đ Acomparative study,”Materials Letters, Vol. 12, 175-178, 1991.

[5] K.C. Nandi, A.K. Biswas andH.N. Acharya, "Density-ofstatesdetermination in hydrogenated amorphous silicon obtained fromrice husk,"Materials Letters,Vol. 12, pp.171-174, 1991.

[6] B.B. Nayak, B.C. Mohanty andS.K. Singh, "Synthesis of silicon carbide from rice husk in a dc arc plasma reactor," Journal of

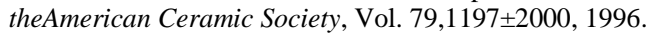

[7] T.B. Ghosh, K.C. Nandi, H.N. Acharya andD. Mukherjee, "XPSstudies of magnesium silicide obtained from rice

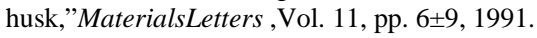

[8] S. Bose, H.N. Acharya andH.D. Banerjee, "Electrical, thermal, thermoelectric and related properties of magnesium silicide semiconductor prepared from rice husk,"Journal of Materials

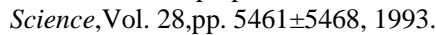

[9] A.Kumar, K. Mohanta, D. Kumar andO.Prakash, "Properties and Industrial Applications of Rice husk: A review,”International Journal of Emerging Technology and Advanced Engineering,Vol. 2, No. 10,pp. 86-90, 2012.

[10] G. Giaccio, G. R. de Sensaleand and R. Zerbino, "Failure mechanism of normal and high strength concrete with rice-huskash", Cement and ConcreteComposites, Vol. 29, pp. 566-574, 2007.

[11] S. K. Bhatnagar, "Fire and Rice Husk Particleboard", Fire andMaterials, Vol. 18, pp. 51-55, 1994.

[12] Fire Tests on Building Materialsand Structures, Part 5. IgnitabilityTest for Materials, BS 476:Part 5: 1968, British StandardsInstitution, London, 1968.

[13] P. Leiva, E. Ciannamea, R. A.Ruseckaite and P. M. Stefani,"Medium-Density Particleboardsfrom Rice Husks and SoybeanProtein Concentrate”, Journal of Applied Polymer Science, Vol. 106, pp.1301-1306, 2007. 